\title{
Peynir altı suyunun bazı tahıl ürünlerinde kullanımı ve kalite özellikleri üzerine etkisi
}

The utilization of whey in some cereal products and its effect on quality properties

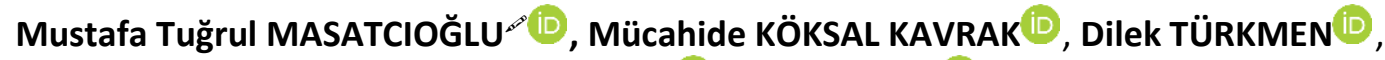 \\ Ahmet DURSUN ${ }^{\mathbb{D}}$, Zehra GÜLER \\ Hatay Mustafa Kemal University, Faculty of Agriculture, Department of Food Engineering, Antakya-Hatay, Turkey.
}

MAKALE BILGISI / ARTICLE INFO

Makale tarihçesi / Article history:

DOI: $10.37908 /$ mkutbd.739234

Geliş tarihi /Received:20.05.2020

Kabul tarihi/Accepted:16.08.2020

\section{Keywords:}

Whey, cookie, noodle, physical and textural properties, sensory attribution.

Corresponding author: M.T.
MASATCIOĞLU
$\square: \underline{\text { tmasatci@gmail.com }}$

\section{Ö Z E T / A B S T R A C T}

\begin{abstract}
Aims: The aim of this study was to investigate the possibilities of using whey, by-product of the cheese industry which is rich in lactose, mineral substances, vitamins and proteins with high biological availability, in cereal products such as cookie and noodle.

Methods and Results: In this study, cookies and noodles were produced by using whey instead of water in their formulations. Physical, sensorial and textural analyses were applied to the control samples and whey supplemented products. According to the results, it has been determined that the spread ratio and lightness values significantly increased in the whey added cookies $(P<0.05)$. On the other hand, the textural and sensorial properties of cookie and noodle samples were not substantially influenced by whey. Using of whey caused a significant increase on cooking loss $(P<0.05)$; however, water absorption, volume increase and cooking time were not remarkably affected from the addition of whey.

Conclusions: The results of this study have shown that the utilization of whey in the formulation of cookie and noodle did not detrimentally affect the quality of them and whey can be used successfully for production of cereal products such as cookies and noodles.

Significance and Impact of the Study: It has been demonstrated that whey, which is a by-product of cheese manufacturing, can be utilized in the development of cereal products without the need of advanced techniques (such as filtration, evaporation, ion exchange) that require high investment and operating costs. Thus, it is thought that evaluating this byproduct instead of removing as waste was considered, and both economic losses and environmental problems can be minimized. In addition, high value added product can be provided to the food industry with present and similar studies.
\end{abstract}

Atıf / Citation: Masatcıoğlu MT, Köksal Kavrak M, Türkmen D, Dursun A, Güler Z (2020) Peynir altı suyunun bazı tahıl ürünlerinde kullanımı ve kalite özellikleri üzerine etkisi. MKU. Tar. Bil. Derg. 25(3) : 422-433. DOI: $10.37908 /$ mkutbd.739234

\section{GiRiş}

Gıda endüstrisinde hammaddelerin ürüne işlenmesi sırasında önemli miktarda yan ürünler oluşmaktadır. Peynir altı suyu (PAS), süt endüstrisinde peynir üretimi sonunda elde edilen önemli bir sütçülük yan ürünüdür (Konar, 1978). PAS; sütün bir organik asit ya da peynir mayası ile pıhtılaştırılmasıyla elde edilen pıhtının ayrılmasından sonra geriye kalan yeşilimsi sarı renkteki sıvı kısımdır (Yerlikaya ve ark., 2010). Peynir üretimi sırasında kullanılan sütün yaklaşık \%85'i PAS olarak ayrılırken (Mete, 2012), önemli besin bileşenlerinden olan protein (albümin, globülin), yağ, laktoz, mineraller (kalsiyum, fosfor, magnezyum, çinko vs.) ve vitaminler 
PAS'a geçmektedir (Kurt, 1990). PAS, süt proteinlerinin yaklaşık \%20'sini içermesinin yanı sıra esansiyel amino asitler ve fonksiyonel özellikleri yüksek proteinlerce zengin olması yönünden de önem taşımaktadır (Yerlikaya vd., 2010). PAS, sülfür içeren amino asitleri (sistein, metiyonin) ve dallı zincirli amino asitleri (lösin, izolösin ve valin) yüksek oranda içerir (Karagözlü ve Bayarer, 2004). Ayrıca, laktoperoksidaz ve laktoferrin gibi minör bileşenleri de ihtiva eden PAS; bileşiminde bulundurduğu tüm bu bileşikler sayesinde insan sağlığı üzerinde son derece faydalı etkilere sahiptir (KavazYüksel ve ark., 2019). Yapılan çalışmalar sonucunda, PAS'da bulunan bileşenlerin, yüksek tansiyon, astım, kanser (kolon, lenf gibi), kas zayıflığı, osteoporoz ve obezite gibi birçok sağlık problemine karşı önleyici veya azaltıcı etkilere sahip olduğu bildirilmiştir (Yerlikaya ve ark., 2010).

PAS, değerlendirilmeden atık halinde doğaya salındığında önemli çevresel sorunlara yol açmaktadır. Bileşimindeki organik madde içeriğinden dolayı PAS, biyolojik oksijen ve kimyasal oksijen gereksinimi yüksek bir yan üründür (Konar, 1978; Guimaraes ve ark., 2010). $\mathrm{Bu}$ nedenle, PAS atıldıkları ortamdaki oksijeni tüketmekte ve ekosistemde bulunan doğal hayata da zarar vermektedir (Kurt ve Gülümser, 1987). Birçok ülkede bu konuda yasal düzenlemeler getirilmiş olup, PAS'ın hiçbir işleme tabi tutulmadan çevreye doğrudan verilmeleri yasaklanmıştır (Konar, 1978). Ayrıca, PAS değerlendirilmeden atık haline dönüştüğünde çevre kirliliğinin yanı sıra önemli ölçüde besin öğesi ve hammadde israfına ve dolayısıyla ekonomik açıdan da kayıplara sebep olabilmektedir (Akyüz, 1979; Mete, 2012). Bu nedenlerle, özellikle gelişmiş ülkelerde sütçülük yan ürünlerinin değerlendirilmesine büyük önem verilmiş, süt endüstrisine paralel olarak yan ürün sanayisi de gelişmiştir (Koyuncu ve Tunçtürk, 2014).

Günümüzde, gelişen teknoloji sayesinde ultrafiltrasyon, mikrofiltrasyon, iyon değişimi, ters osmoz, konsantre etme veya kurutma gibi işlemler kullanılarak çeşitli PAS ürünleri elde edilebilmektedir. Bu işlemler sonucunda PAS tozu, PAS protein konsantreleri, laktoz oranı azaltılmış PAS, demineralize PAS gibi ürünler üretilmekte (Patel ve ark., 1991, Marshall, 2004) ve farklı gıda ve içeceklerin hazırlanmasında çeşitli amaçlarla kullanılmaktadır. Gıda endüstrisinde PAS ve ürünleri; peynir, yoğurt, tereyağı gibi süt ürünlerinin üretiminde, çeşitli içeceklerin yapımında, et ürünlerinde, pastacılık ürünlerinde, maya üretiminde, unlu mamullerde, laktoz ve şurubu üretiminde kullanılmaktadır (Kurt ve Gülümser, 1987; Dinçoğlu ve Ardıç, 2012; Güzeler ve ark., 2017). Ancak PAS'ın işlenerek konsantre veya toz halinde ürünlerin üretilmesi belirli bir yatırım ve işletim maliyeti gerektirmektedir. Türkiye'de, özellikle küçük ölçekli peynir üreten işletmeler maliyetinin yüksek olması nedeniyle PAS'ı kendileri değerlendirememektedir (Akpınar ve ark., 2018). Bunlardan bir kısmı PAS'ı değerlendirmek üzere başka işletmelere ücretsiz verirken (Mete, 2012), büyük bir bölümü ise PAS'ı atık olarak doğrudan çevreye bırakmaktadır (Cansız ve ark., 2020).

Türkiye İstatistik Kurumu (TÜiK) verilerinde, 2019 yılında Türkiye'de yaklaşık 696 bin ton peynir üretildiği ve toplamda 813 bin ton PAS ve yayık altı suyu açığa çıktığı rapor edilmiştir (Anonim, 2019). Fakat peynir üretiminde kullanılan sütün $\% 85^{\prime}$ inin PAS olarak ayrıldığı düşünüldüğünde 2019 yılı için yaklaşık 3,9 milyon ton PAS açığa çıktığı hesap edilebilmektedir. Bu verilerden hareketle PAS'ın önemli bir kısmının işletmeler tarafından değerlendirilmeden atıldığı açıkça görülmektedir. PAS'ın toz forma dönüştürülmeden SIVI halde pastörize edilerek gıda endüstrisinde kullanılması; gerekli maliyetleri düşüreceği için PAS'ın değerlendirilerek kullanımının yaygınlaştırılacağı düşünülmektedir (Demir ve ark., 2009). Bu noktada, pastörize edilmiş PAS'ın doğrudan gıda formülasyonlarına dâhil edilmesi hem atık değerlendirme hem de katma değeri yüksek ürünlerin geliştirilmesi açısından önemli bir araştırma konusu olmaktadır.

Süt ve ürünleri, tahıl ürünlerinin üretiminde teknolojik özellikleri iyileştirmek, besin değerini artırmak ve aroma kazandırmak amacıyla uzun yıllardır kullanılmaktadır. Elzem aminoasitler yönünden fakir olan tahıl ürünlerinin formülasyonlarında PAS ürünlerinin kullanımı, tahıl bazlı ürünlerin elzem aminoasitlerce (özellikle lisin) zenginleştirilmesine katkıda bulunmaktadır (Gökalp ve ark., 1995). Günümüze kadar PAS tozu, PAS protein konsantresi ve PAS protein izolatları kullanılarak ekmek (Ertugay ve ark., 1987; Paul ve ark., 2015; Zhou ve ark., 2016), kek (Díaz-Ramírez ve ark., 2016), bisküvi (Pérez ve ark., 2013; Gani ve ark., 2015; Tang ve Liu, 2017) ve erişte (Aktaş, 2012) gibi birçok tahıl ürünleri geliştirilmesine rağmen pastörize PAS ile üretilen tahıl ürünleriyle yapılan çalışmaların sınırlı olduğu görülmektedir. Bu alanda yapılan çalışmalar özellikle, ekmek formülasyonunda su yerine farklı oranlarda PAS ikame edilmesiyle elde edilen hamur ve ekmeklerde teknolojik kalitenin ve besin değerinin iyileştirilmesine yoğunlaşmıştır (Ertugay ve ark., 1987; Demir ve ark., 2009; Cansız ve ark., 2020). Ancak bisküvi ve erişte gibi yaygın tüketimi olan tahıl ürünlerinin üretiminde PAS kullanımı, hem yan ürünlerin değerlendirilmesi hem de hayvansal besin maddelerince zenginleştirilmiş tahıl 
ürünlerinin geliştirilmesi açısından hâlâ önemini sürdürmektedir.

Bu çalışmada; bisküvi ve erişte üretiminde PAS kullanım olanaklarının araştırılması amaçlanmıştır. Bu kapsamda, üretilen bisküvi ve erişte örneklerinde, fiziksel ve duyusal kalite karakteristiklerinin yanı sıra tüketici beğenisi üzerinde önemli bir kalite parametresi olan tekstürel özellikler (sertlik, kırılganlık, kopma kabiliyeti vb.) de incelenmiştir. Araştırmada ayrıca, PAS ilavesinin incelenen kalite karakteristikleri üzerine etkisi değerlendirilmiştir.

\section{MATERYAL ve YÖNTEM}

Araştırmada, 18A003 no'lu Hatay Mustafa Kemal Üniversitesi, Bilimsel Araştırma Projesi kapsamında gerçekleştirilen Beyaz peynir üretimi sırasında ortaya çıkan PAS materyal olarak kullanılmıştır. Çalışmada kullanılan buğday unu ve diğer bileşenler ise yerel marketlerden temin edilmiştir.

\section{Kimyasal analizler}

Buğday ununun nem, kül, protein ve yağ miktarı sırasıyla, AACCI Metot No: 44.19, 08.01, 46.13 ve 30.25 'e göre belirlenmiştir (AACCI, 2000). PAS'ta kurumadde miktarı, infrared kurutucuda (MB35 Halogen-Ohaus, İsviçre) belirlenmiştir. Sonuçlar gravimetrik yöntemle doğrulanmıştır (AOAC, 2003) ve \% kuru madde olarak hesaplanmıştır. Yağ miktarı Gerber metotla (TSE, 2013) ve $\mathrm{pH}$ değeri dijital $\mathrm{pH}$-metre (Orion, Thermo, Austin, TX, $A B D)$ ile belirlenmiştir. Titrasyon asitliği titrimetrik yöntemle (AOAC, 1995) belirlenmiş ve Soxhlet-Henkel derecesi $\left(\mathrm{SH}^{\circ}\right)$ olarak ifade edilmiştir. Kül miktarı, örneklerin önce $105^{\circ} \mathrm{C}^{\prime}$ de neminin alınmasının ardından $550^{\circ} \mathrm{C}^{\prime}$ ye ayarlanmış kül fırınında (Protherm, PLF 110/10, Türkiye) sabit tartıma gelinceye kadar yakma işlemi gerçekleştirilerek \% olarak hesaplanmıştır. Protein miktarı, Mikro-Kjeldahl metoduna göre (IDF, 1993), toplam azot miktarının belirlenmesi ve ardından 6.38 faktörüyle çarpılması sonucu \% olarak hesaplanmıştır. Laktoz miktarı, Güler (2014) metoduna göre yüksek performanslı sIVI kromatografisi (YPSK) (Shimadzu, Kyoto, Japonya) ile iyon değiştirici kolon (Aminex HPX-87 $\mathrm{H}, 300 \times 7.8 \mathrm{~mm}, \mathrm{BIO}-\mathrm{RAD}$, Hercules, $\mathrm{CA}, \mathrm{ABD}$ ) ile refraktif indeks (RID-10A, Shimadzu, Kyoto, Japonya) dedektörü kullanılarak belirlenmiştir.

\section{Bisküvi üretimi}

Çalışma kapsamında bisküvi üretimleri AACCI Metot No: 10.54 (Wire-cut cookie formulation)'e göre yapılmıştır (AACCI, 2000). Bu yönteme göre üretilen bisküvi örnekleri kontrol grubunu oluştururken, formülasyonda su yerine PAS kullanılan örnekler ise PAS bisküvi olarak adlandırımıştır. Üretimde kullanılan un miktarı $13 \mathrm{~g} / 100$ g nem esasına göre ayarlanmıştır. Eklenecek su miktarı unun nem miktarına göre, PAS miktarı ise hem unun nem miktarı hem de PAS'ın kuru madde içeriği dikkate alınarak hesaplanmıştır. Bisküvi formülasyonunda kullanılan tüm bileşenler ağırlık esasına göre Çizelge 1 'de verilmiştir.

Çizelge 1. Bisküvi formülasyonu ${ }^{a}$

Table 1. Cookie baking formulation ${ }^{\text {a }}$

\begin{tabular}{ll}
\hline Bileşenler & Ağırlık (g) \\
\hline Sakkaroz (İnce Granül Halinde) & 25.6 \\
Kahverengi Şeker & 8.0 \\
Yağsız Süt tozu & 0.8 \\
Tuz & 1.0 \\
Sodyum Bikarbonat & 0.8 \\
Yağ (Shortening) & 32.0 \\
Amonyum Bikarbonat & 0.4 \\
Yüksek Fruktozlu Mısır Şurubu (HFCS) & 1.2 \\
Deiyonize Su veya Peynir Altı Suyu & Değişken $^{\text {b }}$ \\
Unc & 80.0 \\
\hline
\end{tabular}

(a) AACCI, 2000

(b) $\mathrm{Su}(\mathrm{g})=(80-\mathrm{g}$ un $)+17.6$ ve/veya PAS

(c) \%13 nem esasına göre

Çizelge 1'de verilen bileşenler laboratuvar tipi yoğurucunun (KitchenAid, Michigan, ABD) yoğurma haznesine aktarılmış ve 4 . hız kademesinde belirli aralıklarla karıştırma ve sıyırma işlemleri uygulanmıştır. 
Yoğurma işlemi sonunda bisküvi hamurları iki eşit parçaya bölündükten sonra kalıp yardımıyla $7 \mathrm{~mm}$ kalınlık ve $60 \mathrm{~mm}$ çapında yuvarlak hamur parçaları elde edilmiştir. Bisküvi hamurları $200^{\circ} \mathrm{C}$ 'deki fırında (Arçelik, MF35B, Türkiye) 11 dakika pişirilmiş ve 5 dakika dinlendirildikten sonra tepsiden alınmıştır. Bisküvi üretimleri iki farklı günde gerçekleştirilmiş olup, bisküviler hava almayacak şekilde paketlenerek oda sıcaklığında muhafaza edilmiştir. Tüm analizler 2 farklı üretime ait 2 bisküvi üzerinde yapılmış ve sonuçlar 4 bisküviye ait ortalama değerler hesaplanarak verilmiştir.

\section{Erişte üretimi}

Araştırma kapsamında, Yalcin ve Basman (2008) ve Hou (2010) tarafından belirtilen yöntemler modifiye edilerek erişte üretimi gerçekleştirilmiştir. Erişte üretiminde, 100 $\mathrm{g}$ un (\% 13 nem esasına göre), $1.5 \mathrm{~g}$ tuz ve $45-47 \mathrm{~mL}$ saf su veya PAS kullanılmıştır. Üretimde gerekli olan su miktarı ön denemelerle belirlenmiş olup, kontrol grubu eriştelerde $45 \mathrm{~mL}$ saf su kullanılırken PAS erişte grubunda ise $47 \mathrm{~mL}$ PAS kullanılmıştır. Üretim için gerekli malzemeler yoğurucu (Kitchen Aid, Michigan, ABD) haznesine aktarılmış ve her 2 dakikada bir sıyırma işlemi uygulanarak 15 dakika yoğurulmuştur. Elde edilen hamur üzeri kapatılarak oda sıcaklığında 30 dakika dinlendirilmiştir. Erişte hamuru iki eşit parçaya ayrıldıktan sonra erişte inceltme aparatının (Essenso, 981119, Türkiye) 1, 3 ve 5 nolu inceltme bölümlerinden beşer defa geçirilerek inceltilmiştir. Inceltilen hamurlar erişte kesme makinesinden (Tuğra Çelik $150 \mathrm{~mm}$, Türkiye) geçirilerek $5 \mathrm{~mm}$ genişliğinde ve $2 \mathrm{~mm}$ kalınlığında uzun şeritler elde edilmiştir. Uzunluğu $4 \mathrm{~cm}$ olacak şekilde kesilen erişteler birbirine yapışmayacak şekilde tepsilere dizilmiş ve etüvde (Memmert, UE 500, Schwabach, Almanya) $45^{\circ} \mathrm{C}^{\prime}$ de 22 saat kurutulmuştur. Kurutulan erişteler, kilitli polietilen torbalara alınarak analiz edilene kadar oda sıcaklığında muhafaza edilmiştir. Çalışma kapsamında iki ayrı günde 2 farklı erişte üretimi gerçekleştirilmiş olup, analiz sonuçları iki üretimin ortalaması şeklinde verilmiştir.

\section{Bisküvilerde fiziksel analizler}

Üretimden sonra oda sıcaklığına ulaşan bisküvi örneklerinde fiziksel analizler gerçekleştirilmiştir. Bu amaçla, AACCI Metot No: 10.54'e göre dijital kumpas kullanılarak her bir bisküvi örneğinde 3 farklı noktadan ölçüm alınmış ve örneklerin çap ve kalınlıkları belirlenmiştir (AACCI, 2000). Bisküvilerde önemli bir kalite kriteri olan yayılma oranı ise, bisküvi çaplarının kalınlıklarına bölünmesiyle hesaplanmıştır. Ayrıca dijital terazi kullanılarak bisküvi örneklerinin ağırlıkları tespit edilmiştir.
Oda sıcaklığında 24 saat bekletilen bisküvi örneklerinde renk ölçümü Minolta CR-400 cihazı (Konica Minolta, Osaka, Japonya) kullanılarak gerçekleştirilmiştir. Çalışmada, bisküvi örneklerinin yüzeyinde 5 ayrı noktada ölçümler alınarak $L^{*} \quad$ [(0)siyah; (100)beyaz], $a^{*}$ [(+)kırmızı; (-)yeşil] ve $b^{*}[(+)$ sarı; (-)mavi] değerleri belirlenmiştir.

\section{Bisküvilerde tekstürel analizler}

Üretimden sonra oda sıcaklığında 24 saat bekletilen bisküvilerde tekstür analizleri Tekstür Analiz Cihazı (TA50/650E TA.XTPlusC Texture Analyser, Stable Micro Systems, Godalming, Ingiltere) ile gerçekleştirilmiş ve sonuçlar $650 \mathrm{H}$ Exponent Connect yazılımı ile hesaplanmıştır. Tekstür analizlerinde 3 nokta kırma probu (three-point bend rig) ve $5 \mathrm{~kg}$ yükleme hücresi (load cell) kullanılarak 3 nokta kırma testi uygulanmıştır. Analiz öncesi kalibrasyonu yapılan cihazda, prob alt tablası $40 \mathrm{~cm}$ aralıklı olarak ayarlanmış ve prob hareket mesafesi $15 \mathrm{~mm}$, prob test hızı $2 \mathrm{~mm} \mathrm{~s}^{-1}$ olarak belirlenmiştir. Çalışma kapsamında, sertlik (hardness) ve kırılganlık (fracturability) ölçümleri her bir bisküvi grubu için 4 bisküvi üzerinde gerçekleştirilmiş olup, sonuçlar sırasıyla " $\mathrm{g}$ " ve " $\mathrm{mm}$ " cinsinden ortalama olarak verilmiştir.

\section{Bisküvilerin duyusal analizi}

Bisküvilerde tüketici beğenisini ortaya koyabilmek için Suleiman ve ark. (2019) tarafından bildirilen yöntem kullanılarak duyusal analiz gerçekleştirilmiştir. Bu amaçla, 24-43 yaş aralığında 12 panelist ile oluşturulan panelde, katılımcılardan bisküvi örneklerini 1-9 arasındaki hedonik skala (1: hiç beğenmedim, 5: ne beğendim ne beğenmedim, 9: çok beğendim) kullanarak değerlendirmeleri istenmiştir. Duyusal analiz sonunda bisküvi örneklerinin renk, görünüş, tekstür, tat, koku ve genel kabul edilebilirlik değerleri belirlenmiştir.

\section{Eriştelerde pişirme testleri}

Araştırma kapsamında üretilen erişte örneklerinde pişme süresi tayini D’Egidio ve ark., (1982) tarafından bildirilen yönteme göre yapılmıştır. Bu amaçla, kaynayan suyun içine atılan erişte örneklerinden 7. dakikadan itibaren 30 s'de bir örnek alınmış ve iki cam levha arasında sıkıştırılmıştır. Sıkıştırılan erişte örneklerinin ortasındaki pişmemiş açık renkli kısım kaybolana kadar bu işleme devam edilmiş ve pişme süresi belirlenmiştir. Ölçümler 2 tekrarlı olarak gerçekleştirilmiştir.

Suya geçen madde miktarı (SGMM) tayini için behere $250 \mathrm{~mL}$ saf su konulmuş ve kaynatılmıştır. Kaynamakta olan su içerisine atılan 25 g erişte örneği 5 dakikada bir karıştırılarak önceden belirlenen pişme süresi kadar 
pişirilmiştir. Süre sonunda beher içeriği süzülmüş ve erişteler tekrar pişirme kabına alınmıştır. Behere $90 \mathrm{~mL}$ saf su ilave edilerek erişte örneklerine yıkama işlemi uygulanmış ve tekrar süzülmüştür. Başlangıçtaki pişirme suyu ve yıkama suyu bir araya getirilerek hacim saf su ile $350 \mathrm{~mL}$ 'ye tamamlanmıştır. Homojen bir şekilde karıştırılan sıvı karışımından alınan $50 \mathrm{~mL}$ örnek, önceden darası belirlenmiş bir behere aktarılmış ve etüvde (Memmert, UE 500, Schwabach, Almanya) $98^{\circ} \mathrm{C}^{\prime}$ de sabit ağırlığa gelinceye kadar kurutulmuştur. Beherler desikatörde soğutulmuş ve ardından tartılmıştır. Suya geçen madde miktarı aşağıdaki formül (Eşitlik 1) yardımıyla hesaplanmıştır (Köksel ve ark., 2000). Ölçümler 2 tekrarlı olarak gerçekleştirilmiştir.

$\operatorname{SGMM}(\%)=\frac{\mathrm{G} \times 28}{100-\mathrm{R}} \times 100$

G: Kalıntı Miktarı (etüvde kurutulduktan sonra boş ve pişirme suyu içeren kap ağırlıkları arasındaki fark)

R: Erişte Nem Miktarı (\%)

SGMM analizinde elde edilen pişmiş erişte örnekleri süzülerek tartılmış ve pişmiş erişte ağırlığı $\left(G_{2}\right)$ tespit edilmiştir. Pişirilmiş erişte ağırlığı değerinden $\left(\mathrm{G}_{2}\right)$ pişirilmemiş erişte ağırlığı $\left(G_{1}=25\right.$ g) çıkarılarak pişirme işlemi sonucu erişte örneklerinde meydana gelen ağılık artışı tespit edilmiştir. Erişte örneklerinde su absorpsiyon değeri (\%) aşağıdaki formül (Eşitlik 2) kullanılarak hesaplanmıştır (Köksel ve ark., 2000). Ölçümler 2 tekrarlı olarak gerçekleştirilmiştir.

Su Absorpsiyonu $(\%)=\frac{\left(\mathrm{G}_{2}-\mathrm{G}_{1}\right)}{\mathrm{G}_{1}} \times 100$

Hacim artışı analizi için 250 mL'lik ölçü silindirine, erişte örneklerinin üzerini kaplayacak kadar $(100 \mathrm{~mL})$ saf su konulmuş ve üzerine $25 \mathrm{~g}$ erişte ilave edilmiştir. Su seviyesindeki artış ölçülerek kuru erişte hacmi $\left(V_{1}\right)$ belirlenmiştir. Aynı işlem SGMM analizinde pişirilmiş ve süzülmüş erişte örnekleri için de tekrarlanarak pişmiş erişte hacmi $\left(V_{2}\right)$ tespit edilmiştir. Erişte örnekleri için hacim artışı (\%) aşağıda verilen eşitlik (Eşitlik 3) kullanılarak hesaplanmıştır (Köksel ve ark., 2000). Ölçümler 2 tekrarlı yürütülmüştür.

Hacim Artı̧̧1 $(\%)=\frac{\left(V_{2}-V_{1}\right)}{V_{1}} \times 100$

\section{Eriştelerde renk ve tekstür analizleri}

Araştırma kapsamında üretilen erişte örnekleri, kahve değirmeninde öğütülerek $500 \mu$ m’lik elekten geçirilmiş ve Minolta CR-400 cihazı (Konica Minolta, Osaka, Japonya) kullanılarak renk değerleri ölçülmüştür. 3 tekrarlı olarak yürütülen analiz sonucunda erişte örneklerinin $L^{*}, a^{*}$ ve $b^{*}$ değerleri belirlenmiştir.

Tekstür analizi için erişte örnekleri çalışmada belirlenen pişme süresi kadar pişirilmiş ve oda sıcaklığında 5 dakika süresince soğutulmuştur. Erişte örneklerinde tekstür analizleri Tekstür Analiz Cihazı (TA50/650E TA.XTPlusC Texture Analyser, Stable Micro Systems, Godalming, Ingiltere) kullanılarak gerçekleştirilmiştir. Sonuçlar $650 \mathrm{H}$ Exponent Connect yazılımı ile hesaplanmıştır. Analizlerde $5 \mathrm{~kg}$ yükleme hücresi (load cell) ve Kieffer Dough and Gluten Extensibility Rig probu kullanılmıştır. Probun sıfır ayarı yapıldıktan sonra test hızı $3 \mathrm{~mm} \mathrm{~s}^{-1}$ olarak belirlenmiş ve her erişte grubu için 6 tekrarlı analiz gerçekleştirilmiştir. Analiz sonucunda pişirilmiş erişte örneklerini koparmak için gerekli maksimum kuvvet $(\mathrm{N})$ belirlenmiştir.

\section{Eriştelerin duyusal analizi}

Üretilen erişte örneklerinin duyusal değerlendirilmesi Yalcin ve Basman (2008) tarafından bildirilen yönteme göre yapılmıştır. Pişirildikten sonra 2 dakika dinlendirilen erişte örnekleri 21-32 yaş aralığındaki 10 paneliste sunulmuştur. Erişte örneklerinin duyusal değerlendirmesi, yüzey özellikleri, çiğneme özellikleri, çiğneme sonrası ağızdaki his özellikleri ve tat parametreleri dikkate alınarak 1-5 skalasında gerçekleştirilmiştir.

\section{Istatistiksel analiz}

Elde edilen veriler SPSS programı (IBM SPSS Statistics 24.0, IBM Corp., NY, ABD) kullanılarak analiz edilmiş ve ortalamalar bağımsız örnekler t-testi ile karşılaştııılmıştır. Farklar anlamlı bulunduğunda önem düzeyi belirtilmiştir. Sonuçlar, ortalama \pm standart sapma değerleriyle ifade edilmiştir.

\section{BULGULAR ve TARTIŞMA}

\section{Un ve PAS'ın kimyasal özellikleri}

Bisküvi ve erişte üretiminde kullanılan buğday ununun kimyasal özelliklerinden nem, kül, protein ve yağ miktarları sırasıyla; \%10.87, \%0.51, \%11.61 ve \%1.49 olarak tespit edilmiştir. Formülasyonda kullanılan PAS'a ait kimyasal analiz sonuçları Çizelge 2'de verilmiştir. 
Çizelge 2. PAS kimyasal analiz sonuçları

Table 2. Chemical composition of whey

\begin{tabular}{ll}
\hline Nitelikler & Değerler \\
\hline Kurumadde (\%) & $7.21 \pm 0.01$ \\
Yağ (\%) & $0.40 \pm 0.00$ \\
Titrasyon asitliği $\left({ }^{\circ} \mathrm{SH}\right)$ & $14.68 \pm 0.00$ \\
$\mathrm{pH}$ & $4.99 \pm 0.01$ \\
Kül $(\%)$ & $0.50 \pm 0.01$ \\
Protein $(\%)$ & $1.3 \pm 0.00$ \\
Laktoz $(\mathrm{g} / 100 \mathrm{~mL})$ & $5.04 \pm 0.03$ \\
\hline
\end{tabular}

\section{Bisküvilerin fiziksel özellikleri}

Çalışma kapsamında üretilen bisküvi örneklerine ait çap, kalınlık, yayılma oranı ve ağılık değerleri Çizelge 3'te verilmiştir. Formülasyonda su yerine PAS kullanımının bisküvilerin çap, kalınlık, yayılma oranı ve ağırlık değerlerini önemli düzeyde etkilediği saptanmıştır. Üretimde PAS kullanıldığında bisküvi çaplarının istatistiksel olarak artış gösterdiği $(P<0.001)$, bisküvi kalınlıklarının ise azaldığı $(P<0.05)$ tespit edilmiştir. Bisküvilerdeki çap ve kalınlık değişimine bağlı olarak yayılma oranının PAS bisküvi örneklerinde kontrole göre yüksek olduğu belirlenmiştir $(P<0.05)$. Literatür incelendiğinde, formülasyonuna doğrudan PAS ilave edilerek üretilen bisküvilerin fiziksel kalite özellikleri üzerine yapılmış bir araştırmaya rastlanmamıştır. Gani ve ark. (2015)'nın yaptığı çalışmada PAS protein konsantresi ve PAS protein izolatı kullanımının bisküvilerin yayılma oranı üzerinde önemli bir etkisinin olmadığı bildirilmiştir. Tang ve Lui (2017)'nin çalışmasında ise, formülasyonda kullanılan PAS protein oranı (\%0-30) arttıkça yayılma oranının azaldığı rapor edilmiştir. Yayılma oranı bisküvilerde önemli bir fiziksel kalite kriteri olup, yayılma oranı arttıkça bisküvi kalitesinin arttığı birçok çalışmada bildirilmiştir (Yamamoto ve ark., 1996; Marques ve ark., 2016; Kaur ve ark., 2017). Dolayısıyla, formülasyonda doğrudan PAS kullanımının bisküvi kalitesinin iyileştirilmesi açısından PAS ürünlerine (PAS proteini, PAS protein hidrolizatı, PAS protein konsantresi vb.) kıyasla daha etkili olduğu görülmektedir.

Çizelge 3. Bisküvi örneklerinin çap, kalınlık, yayılma oranı ve ağırlık değerleri

Table 3. Diameter, thickness, spread ratio and weight values of cookies

\begin{tabular}{lllll}
\hline Örnek & Çap $(\mathbf{m m})$ & Kalınlık $(\mathbf{m m})$ & Yayılma Oranı & Ağırlık $(\mathbf{g})$ \\
\hline Kontrol Bisküvi & $66.87 \pm 0.87$ & $13.50 \pm 0.32$ & $4.95 \pm 0.16$ & $23.32 \pm 0.06$ \\
PAS Bisküvi & $68.85 \pm 0.92$ & $13.22 \pm 0.16$ & $5.21 \pm 0.05$ & $23.81 \pm 0.10$ \\
${ }^{\ddagger} \boldsymbol{P}$ & $* * *$ & $*$ & $*$ & $* * *$
\end{tabular}

\#Örnekler arasındaki farklılıkları ifade etmektedir. ${ }^{*} P<0.05,{ }^{* * *} p<0.001$

Üretilen bisküvi örneklerinin renk özellikleri Çizelge 4'te sunulmuştur. PAS kullanımı bisküvi örneklerinin $L^{*}$ ve $a^{*}$ değerlerini önemli bir düzeyde etkilerken, $b^{*}$ değeri üzerinde ise istatistiksel olarak önemli bir etkisinin olmadığı tespit edilmiştir. PAS ilavesinin bisküvilerin $L^{*}$ değerini artırdığı $(P<0.05)$, kontrol grubu bisküvilerle kıyaslandığında $a^{*}$ değerinin düştüğü $\left(\begin{array}{ll}P & <0.05\end{array}\right)$ saptanmıştır.

Çizelge 4. Bisküvi örneklerinin renk ve tekstürel özellikleri

Table 4. Color and textural properties of cookies

\begin{tabular}{llllll}
\hline Örnek & $\boldsymbol{L}^{*}$ & $\boldsymbol{a}^{*}$ & $\boldsymbol{b}^{*}$ & Sertlik (g) & Kırılganlık (mm) \\
\hline Kontrol Bisküvi & $68.45 \pm 0.83$ & $7.23 \pm 0.23$ & $35.06 \pm 0.70$ & $2589.60 \pm 186.58$ & $42.17 \pm 0.42$ \\
PAS Bisküvi & $72.26 \pm 0.59$ & $5.47 \pm 0.35$ & $34.86 \pm 0.65$ & $2335.06 \pm 138.85$ & $41.90 \pm 0.32$ \\
$\boldsymbol{P}$ & $*$ & $*$ & ö.d. & o.d. & ö.d.
\end{tabular}

* $P<0.05$, ö.d.: İstatistiksel olarak önemli değil; $P>0.05$

PAS'ın riboflavin açısından zengin olduğu ve bundan dolayı karakteristik sarı-yeşil renge sahip olduğu bilinmektedir (Yerlikaya ve ark., 2010). Bu nedenle, PAS kullanılarak üretilen bisküvilere ait renk değerlerindeki 
bu farklılığın PAS'ın kendine özgü bileşiminden kaynaklandığı anlaşılmaktadır. Benzer şekilde, bazı çalışmalarda farklı oranlarda PAS kullanılarak üretilen örneklerde ekmek içi renginde $L^{*}$ değerinde artış olduğu $a^{*}$ ve $b^{*}$ değerlerinde ise, önemli bir değişim olmadığı rapor edilmiştir (Demir ve ark., 2009; Cansız ve ark., 2020).

\section{Bisküvilerin tekstürel özellikleri}

Gıda ürünlerinde tekstürel özellikler, görünüş ve lezzetin yanı sıra tüketici beğenisi açısından önemli bir kalite kriteridir (Bourne, 1990). Bu çalışmada, PAS ilavesinin bisküvi örneklerinin tekstürel özelliklerinden sertlik ve kırılganlık değerleri üzerine dikkate değer bir etkisinin olmadığı belirlenmiştir (Çizelge 4). Kontrol grubu bisküvilerin sertlik değerleri rakamsal olarak PAS ilaveli bisküvilerin değerlerinden yüksek olsa da ortalama değerler arasındaki fark istatistiksel olarak anlamlı bulunmamıştır. Bir diğer ifadeyle, formülasyonda su yerine PAS kullanıldığında bisküvilerin tekstürel özelliğinin olumsuz etkilenmediği, PAS bisküvi örneklerinin de kontrol bisküvilere eşdeğer tekstürü sağlayabileceği görülmüştür. Formülasyonunda PAS kullanılarak üretilen ekmek örneklerinde de benzer sonuçlar rapor edilmiştir (Demir ve ark., 2009; Cansız ve ark., 2020). Bunun aksine, PAS protein ürünleri kullanıldığında ise, ilave oranı artışıyla bisküvi sertliğinde belirgin bir artış olduğu bildirilmiştir (Gani ve ark., 2015; Tang ve Lui, 2017).

\section{Bisküvilerin duyusal özellikleri}

Çalışma kapsamında üretilen bisküvilerin duyusal özelliklerine ait sonuçlar Çizelge 5'te verilmiştir. PAS bisküvi örneklerinin 12 kişilik panelist grup tarafından 9 puanlık hedonik skalada 5 ve üzerinde puanlar aldığı tespit edilmiştir. İncelenen parametreler (renk, görünüş, tekstür, tat ve koku) açısından kontrol grubu ile kıyaslandığında yakın skorlar elde edilmiş ve bu nedenle bisküvilerin duyusal özellikler yönünden kabul edilebilir olduğu değerlendirilmiştir. Benzer sonuçlar ekmek formülasyonunda farklı oranlarda PAS kullanan Cansız ve ark. (2020) tarafından da rapor edilmiştir. PAS'ın aksine bisküvi üretiminde PAS proteini veya PAS protein hidrolizatı kullanıldığında ise, ilave oranı arttırıldıkça (\%015; \%0-30) bisküvilerin duyusal olarak kabul edilebilirliğinin düştüğü bildirilmiştir. PAS proteini veya ürünleri kullanıldığında bisküvilerin sert bir yapı kazanması, renginin koyulaşması ve istenmeyen acı bir tat oluşumunun tüketici beğenisindeki azalmadan sorumlu olduğu ifade edilmiştir (Gani ve ark., 2015; Tang ve Lui, 2017).

Çizelge 5. Bisküvi örneklerine ait duyusal analiz değerleri

Table 5. Sensory properties of cookies

\begin{tabular}{lcccccc}
\hline Örnek & Renk & Görünüş & Tekstür & Tat & Koku & $\begin{array}{c}\text { Genel Kabul } \\
\text { Edilebilirlik }\end{array}$ \\
\hline Kontrol Bisküvi & $7.0 \pm 1.7$ & $7.6 \pm 0.9$ & $5.4 \pm 2.4$ & $6.0 \pm 2.2$ & $6.8 \pm 2.2$ & $6.3 \pm 1.7$ \\
PAS Bisküvi & $7.1 \pm 1.6$ & $7.8 \pm 1.1$ & $5.0 \pm 2.1$ & $5.9 \pm 2.2$ & $6.8 \pm 2.5$ & $6.3 \pm 1.6$ \\
$\boldsymbol{P}$ & ö.d. & ö.d. & ö.d. & ö.d. & ö.d. & o.d. \\
\hline
\end{tabular}

ö.d.: Istatistiksel olarak önemli değil; $P>0.05$

\section{Eriştelerin pişme özellikleri}

Makarna, erişte tipi ürünlerin kalitesinin değerlendirilmesinde pişirme testleri en geçerli yöntemdir (Özkaya ve ark., 1984). Çalışma kapsamında kontrol grubu erişte ve formülasyonunda su yerine PAS ilave edilerek üretilen erişte örneklerine ait pişme özellikleri Çizelge 6 'da gösterilmiştir. Kontrol grubu ile PAS erişte örneklerine ait pişme süreleri sırasıyla; 13 ve 12 dakika olarak belirlenmiş ve PAS kullanımının pişme süresini önemli düzeyde etkilemediği tespit edilmiştir. Buğday unu ile üretilen eriştelerin ortalama pişme süresi literatürde 10-16 dakika olarak rapor edilmiştir (Oh ve ark., 1985). Çalışmada belirlenen pişme sürelerinin önceki çalışmalarla uyumlu olduğu görülmektedir.

Makarna ve erişte kalitesinin belirlenmesinde pişme suyuna geçen madde miktarı (SGMM) önemli bir kalite parametresidir ve pişme sırasında üründen suya geçen madde miktarını ifade etmektedir (Demir, 2008). Bu çalışmada, PAS erişte örneklerinin SGMM değerlerinin (\%11.30) kontrol erişte örneklerine (\%9.73) kıyasla yüksek olduğu belirlenmiştir (Çizelge 6). Erişte kalitesini değerlendirmede SGMM değerinin düşük olması arzu edilen bir durumdur. Bu bağlamda, SGMM değeri $\% 10$ 'un üzerinde olan örnekler düşük kaliteli olarak değerlendirilmektedir (Özkaya ve ark., 1984). Ancak geleneksel yöntemlerle irmik yerine buğday unu kullanılarak üretilen eriştelerin yüksek SGMM değerlerine sahip olduğu da bilinmektedir (Akillioglu ve Yalcin, 2010). Benzer şekilde Aktaş (2012), PAS tozu ve PAS protein konsantresi ikame edilerek üretilen erişte örneklerine ait SGMM değerlerinin, kontrol eriştelerden daha yüksek olduğunu rapor etmiştir. Formülasyonda 
kullanılan PAS ürünlerindeki laktozun pişme sırasında SGMM değerlerinin artmasına neden olduğu bildirilmiştir (Aktaş, 2012).

Pişme sırasında eriştelerin absorbe ettiği su miktarı ile ilişkili olan su absorpsiyonu ve hacim artışı değerleri, pişirilmiş eriştenin arzu edilen tekstürel yapıya sahip olması açısından önemli kalite parametreleridir (Bhattacharya ve ark., 1999). Kontrol grubu erişte ile kıyaslandığında, PAS kullanımının erişte örneklerinin su absorpsiyonu ve hacim artışı değerleri üzerinde önemli bir etkisinin olmadığı saptanmıştır (Çizelge 6). Su absorpsiyonu ve hacim artışı değerleri arttıkça ürün kalitesinin de arttığı bilinmektedir (Köksel ve ark., 2000). PAS tozu ve PAS proteini kullanılarak erişte üretiminin yapıldığı bir çalışmada, eriştelerin su absorpsiyonu ve hacim artışı değerlerinin sırasıyla \%104.237 ve \%130.428 olduğu bidirilmiştir (Aktaş, 2012). Bu çalışmada elde edilen değerlerin (sırasıyla; \%180.9 ve \%221.1), Aktaş (2012) tarafından bildirilen değerlerden yüksek olduğu görülmektedir. Başka bir araştırmada, PAS protein konsantresi ilave edilen noodle örneklerinde su absorpsiyonu ve hacim artışı değerlerinin düştüğü ve SGMM değerinin ise, kontrol örneğine göre artış gösterdiği $(P<0.01)$ bildirilmiştir (Baskaran ve ark., 2011). Dolayısıyla, eriştenin pişme özelliklerinin iyileştirilmesinde doğrudan PAS kullanımının PAS ürünlerine (PAS tozu, PAS proteini, ve PAS protein konsantresi) göre daha avantajlı olduğu anlaşılmaktadır.

Çizelge 6. Erişte örneklerinin pişme özellikleri

Table 6. Cooking characteristics of noodles

\begin{tabular}{lcccc} 
Örnek & $\begin{array}{c}\text { Pişme Süresi } \\
\text { (dk) }\end{array}$ & $\begin{array}{c}\text { Suya Geçen Madde } \\
\text { Miktarı (\%) }\end{array}$ & $\begin{array}{c}\text { Su Absorpsiyonu } \\
\text { (\%) }\end{array}$ & $\begin{array}{c}\text { Hacim Artışı } \\
\text { (\%) }\end{array}$ \\
\hline Kontrol Erişte & $13.0 \pm 0.7$ & $9.73 \pm 0.10$ & $176.7 \pm 3.9$ & $215.0 \pm 7.1$ \\
PAS Erişte & $12.0 \pm 0.7$ & $11.30 \pm 0.07$ & $180.9 \pm 1.2$ & $221.1 \pm 7.4$ \\
$\boldsymbol{P}$ & ö.d. & $*$ & ö.d. & o.d.
\end{tabular}

${ }^{*} P<0.05$, ö.d.: Istatistiksel olarak önemli değil; $P>0.05$

\section{Eriştelerin renk ve tekstürel özellikleri}

Renk özellikleri erişte kalitesinde etkili bir kalite parametresidir ve sarı renk ile parlak görünüş eriştelerde istenen bir özelliktir (Akillioglu ve Yalçın, 2010). Üretilen kontrol ve PAS erişte örneklerinin renk değerleri Çizelge 7'de sunulmuştur. Formülasyonda PAS kullanımının, erişte örneklerinin $L^{*}$ ve $b^{*}$ değerlerini dikkate değer seviyede etkilemediği, ancak $a^{*}$ değerini istatistiksel olarak önemli düzeyde düşürdüğü $\left(\begin{array}{ll}P & <0.05\end{array}\right)$ belirlenmiştir. PAS erişte örneklerinin $a^{*}$ değerinde meydana gelen bu değişimin (yeşilimsi renk değerinin kısmen artması), PAS içeriğindeki riboflavinden kaynaklandığı düşünülmektedir.

Üretilen erişte örneklerinin pişirildikten sonra kopmaya karşı gösterdiği maksimum kuvvet değerleri belirlenmiş, elde edilen veriler Çizelge 7'de verilmiştir. Değerler incelendiğinde, PAS kullanımının erişte örneklerinin tekstürel özellikleri üzerine önemli bir etkisinin olmadığı belirlenmiştir. Pişmemiş erişte örneklerinde kırılma kuvvetinin belirlendiği bir çalışmada, PAS ürünleri ilave edilerek üretilen eriştelerin kırılma kuvveti değerlerinin ilave oranının artışıyla (\%0-10) birlikte azaldığı rapor edilmiştir (Aktaş 2012). Formülasyona toz formda dâhil edilen PAS ve PAS proteinlerinin, gluten yapısındaki sürekliliği bozarak eriştelerin kırılganlığının artmasına ve pişmeye karşı dayanıklılığının azalmasına neden olduğu ifade edilmiştir (Aktaş, 2012). Çalışma kapsamında üretilen erişteler hem renk hem de kopmaya karşı gösterdiği kuvvet özellikleri bakımından değerlendirildiğinde, formülasyonda su yerine PAS kullanımının erişte kalitesini olumsuz yönde etkilemediği saptanmıştır.

Çizelge 7. Erişte örneklerinin renk ve maksimum kuvvet değerleri

Table 7. Color and maximum strength values of noodle

\begin{tabular}{lcccc}
\hline Örnek & $\boldsymbol{L}^{*}$ & $\boldsymbol{a}^{*}$ & $\boldsymbol{b}^{*}$ & Maksimum Kuvvet (N) \\
\hline Kontrol Erişte & $84.37 \pm 0.90$ & $-1.08 \pm 0.12$ & $15.04 \pm 0.86$ & $0.54 \pm 0.03$ \\
PAS Erişte & $86.40 \pm 1.12$ & $-1.43 \pm 0.06$ & $14.99 \pm 1.63$ & $0.56 \pm 0.03$ \\
$\boldsymbol{P}$ & o.d. & $*$ & ö.d. & o.d. \\
\hline
\end{tabular}

*P<0.05, ö.d.: İstatistiksel olarak önemli değil; $P>0.05$ 


\section{Eriştelerin duyusal özellikleri}

Erişte örneklerinde tüketici beğenisinin değerlendirilmesi amacıyla duyusal analiz gerçekleştirilmiştir. On panelistin katıldığı panelde tüketiciler, pişmiş erişte örneklerini kayganlık, pürüzlülük, sertlik, yapışkanlık, kumluluk gibi yüzey ve çiğneme özellikleri ile tat kriterleri açısından değerlendirmişlerdir. Pişirilmiş erişte örneklerine ait duyusal değerlendirme puanları Çizelge $8^{\prime} \mathrm{de}$ gösterilmiştir. Yapılan duyusal analiz sonucunda, PAS erişte örneklerinin kontrol erişte örnekleri ile benzer puanlar aldığı tespit edilmiş ve erişteler istatistiki olarak birbirinden farklı bulunmamıştır. Duyusal kalite özellikleri 1-5 hedonik skala üzerinden değerlendirilen erişte örneklerinin orta değer olan 3 ve üzerinde puanlar aldığı belirlenmiş ve bu nedenle eriştelerin duyusal açıdan kabul edilebilir olduğu sonucuna varılmıştır.

Çizelge 8. Erişte örneklerine ait duyusal analiz değerleri

Table 8. Sensory properties of noodles

\begin{tabular}{lcccc}
\hline Örnek & $\begin{array}{c}\text { Yüzey } \\
\text { Özellikleri }\end{array}$ & Çiğneme Özellikleri & $\begin{array}{c}\text { Çiğneme Sonrası Ağızdaki } \\
\text { His Özellikleri }\end{array}$ & Tat \\
\hline Kontrol Erişte & $3.6 \pm 0.5$ & $3.1 \pm 1.0$ & $4.1 \pm 0.7$ & $3.6 \pm 1.0$ \\
PAS Erişte & $3.9 \pm 0.8$ & $3.7 \pm 0.7$ & $4.0 \pm 1.0$ & $3.2 \pm 1.2$ \\
$\boldsymbol{P}$ & ö.d. & ö.d. & ö.d. & ö.d. \\
\hline
\end{tabular}

ö.d.: Istatistiksel olarak önemli değil; $P>0.05$

\section{Sonuç ve Öneriler}

Çalışmada, süt işletmelerinde yan ürün olarak ortaya çıkan PAS'ın tahıl ürünlerinde kullanım olanaklarının araştırılması amacıyla bisküvi ve erişte üretimleri gerçekleştirilmiştir. Bu kapsamda, PAS kullanılarak üretilen ürünlerin bazı fiziksel, duyusal ve tekstürel özellikleri kontrol grubu örneklerle kıyaslanmıştır. Araştırma bulguları incelendiğinde, PAS kullanımının bisküvi kalitesinin değerlendirilmesinde önemli bir kriter olan yayılma oranı üzerinde olumlu bir etkisinin olduğu tespit edilmiştir. Ayrıca, PAS ilaveli bisküvilerin $L^{*}$ değerinin kontrol grubu bisküvilere kıyasla yüksek olduğu ve PAS ürünlerinin (PAS proteini, PAS protein konsantesi, PAS protein hidrolizatları gibi) aksine parlaklığı azaltıcı etkisinin olmadığı belirlenmiştir. Bisküvilerin tekstürel ve duyusal özellikleri değerlendirildiğinde, örnekler arasında dikkate değer bir farklılık görülmemiştir. PAS ilavesinin erişte örneklerine ait pişme özelliklerinden SGMM değerini arttırdığı ancak, diğer parametreleri etkilemediği saptanmıştır. Bunların yanı sıra renk, tekstür ve duyusal analiz değerlerine göre PAS erişte örneklerinin kontrol erişte örnekleriyle eşdeğer özelliklere sahip olduğu görülmüştür.

Sonuç olarak, formülasyonda su yerine PAS kullanımının bisküvi ve erişte kalitesini olumsuz yönde etkilemediği ve PAS'ın tahıl ürünlerinin üretiminde kullanımının uygun olduğu tespit edilmiştir. Dolayısıyla, besleyici değeri olan PAS'ın gıdaların üretiminde yeniden bir girdi olarak kullanılması hem çevre kirliliğini önlemek hem de yeterli ve dengeli beslenmeye katkıda bulunmak açısından fayda sağlayacaktır. PAS'ın ultrafiltrasyon, evaporasyon, ters osmoz, iyon değişim gibi işlemler uygulanmadan ürün geliştirmede kullanımı, yatırım ve işletim maliyetlerinin önemli ölçüde azaltılmasına ve ayrıca zaman ve işgücünden tasarruf edilmesine olanak sunacaktır.

\section{ÖZET}

Amaç: Süt endüstrisinin laktoz, mineral maddeler, vitaminler ve biyolojik yararlılığı yüksek proteinlerce zengin bir yan ürünü olan peynir altı suyunun (PAS) bisküvi ve erişte ürünlerinde kullanım olanaklarının araştırılması amaçlanmıştır.

Yöntem ve Bulgular: Çalışmada, formülasyonlarında su yerine PAS kullanılarak bisküvi ve erişte üretimleri gerçekleştirilmiştir. Kontrol grubu örnekler ve PAS ilave edilerek üretilen ürünlere fiziksel, duyusal ve tekstürel analizler uygulanmıştır. Buna göre, PAS kullanımının bisküvilerde yayılma oranını ve parlaklık değerini önemli düzeyde arttırdığı $(P<0.05)$ tespit edilmiştir. Diğer taraftan, bisküvi ve erişte örneklerinin tekstürel ve duyusal özellikleri üzerinde ise PAS ilavesinin önemli bir etkisinin olmadığı görülmüştür. Erişte örneklerinin pişme kalitesi değerlendirildiğinde, PAS kullanımının suya geçen madde miktarını arttırdığı $(P<0.05)$ ancak su absorpsiyonu, hacim artışı ve pişme süresi üzerine önemli bir etkisinin olmadığı belirlenmiştir.

Genel Yorum: Formülasyonda su yerine PAS kullanımının bisküvi ve erişte kalitesini olumsuz yönde etkilemediği ve PAS'ın bisküvi ve erişte ürünlerinin üretiminde başarılı bir şekilde kullanılabileceği sonucuna varılmıştır.

Çalışmanın Önemi ve Etkisi: Bu çalışma ile, peynir yapımı sırasında ortaya çıkan PAS'ın, yüksek yatırım ve işletim maliyeti gerektiren ileri tekniklere (filtrasyon, evaporasyon, iyon değişim gibi) ihtiyaç duyulmaksızın, 
tahıl ürünlerinin üretiminde kullanılabileceği ortaya konmuştur. Böylece atık durumuna düşen bu ürünün değerlendirilerek hem ekonomik kayıpların engelleneceği hem de çevresel sorunların azaltılabileceği düşünülmektedir. Ayrıca, bu ve buna benzer çalışmalarla gıda endüstrisine yüksek katma değer sağlanabilecektir.

Anahtar Kelimeler: Peynir altı suyu, bisküvi, erişte, fiziksel ve tekstürel özellikler, duyusal özellikler.

\section{TEŞEKKÜR}

Araştırma, 18A003 proje numarası ile Hatay Mustafa Kemal Üniversitesi BAP birimi tarafından desteklenmiştir.

\section{ÇIKAR ÇATIŞMA BEYANI}

Yazarlar çalışma konusunda çıkar çatışmasının olmadığını beyan eder.

\section{ARAŞTIRMACILARIN KATKI ORANI BEYANI}

M. Tuğrul Masatcıoğlu: Kavramsallaştırma, Metodoloji, Biçimsel analiz, Yazma - orijinal taslak, Yazma - inceleme ve düzenleme, Görselleştirme. Mücahide Köksal Kavrak: Metodoloji, Biçimsel analiz, Yazma - orijinal taslak, Yazma - inceleme ve düzenleme, Görselleştirme. Dilek Türkmen: PAS üretimi, PAS analizleri. Ahmet Dursun: PAS üretimi, PAS analizleri. Zehra Güler: Kavramsallaştırma, Metodoloji, Yazma - inceleme ve düzenleme, Görselleştirme, Proje Yönetimi.

\section{KAYNAKLAR}

AACCI (2000) American Association of Cereal Chemists, approved methods of the AACC International, $10^{\text {th }}$ ed. Methods: 10.54, 44.19, 08.01, 46.13 and 30.25. St. Paul, MN, USA.

AOAC (1995) Official Methods of Analysis. Vol. II., 16th ed. AOAC International, Arlington, VA.

AOAC (2003) Official Methods of Analysis. AOAC International, Washington, DC.

Akillioglu HG, Yalcin E (2010) Some quality characteristics and nutritional properties of traditional egg pasta (erişte). Food Sci. Biotechnol. 19(2): 417-424.

Akpınar A, Yerlikaya O, Akan E, Uysal HR (2018) Peyniraltı suyu ve Türkiye'de değerlendirilmesi. e-TRALLEIS, 3(2): 104-112.

Aktaş K (2012) Sütçülük yan ürünleri ve $\beta$-glukan ilavesi ile eriştenin besinsel özelliklerinin artırılması üzerine bir araştırma. Yüksek Lisans Tezi, Selçuk Üni., Fen Bil. Ens., Gıda Mühendisliği ABD, 101 s.
Akyüz N (1979) Süt endüstrisinde yan ürünlerin değerlendirilmesi ve önemi. Atatürk Üni. Zir. Fak. Derg. 10(1-2): 207-216.

Anonim (2019) Türkiye İstatistik Kurumu Süt ve Süt Ürünleri Üretim Miktarı İstatistikleri. https://biruni.tuik.gov.tr/medas/?locale=tr. (Erişim Tarihi: 27.04.2020)

Baskaran D, Muthu Pandian K, Gnanalaksshmi KS, Pugazenthmi TR, Jothylingam S, Ayyadurai K (2011) Physical proporties of noodles enriched with whey protein concentrate and skim milk powder. J Stored Prod. Postharvest Res. 2(6): 127-130.

Bhattacharya M, Zee SY, Corke H (1999) Physicochemical properties related to quality of rice noodles. Cereal Chem. 76(6): 861-867.

Bourne MC (1990) Basic principles of food texture measurement, In: Dough Rheology and Baked Product Texture (Eds. Faridi H, Faubion JM), AVI Van Nostrand Reinhold, New York, p. 331.

Cansız Z, Candal Uslu C, Mutlu C, Arslan Tontul S, Ercan $R$, Erbaş M (2020) Farklı oranlarda peynir altı suyu kullanımının beyaz ve tam buğday unlarından üretilen ekmeklerin bazı özellikleri üzerine etkisi. Gıda, 45(1): 125-138.

Demir B (2008) Nohut ununun geleneksel erişte ve kuskus üretiminde kullanım imkanları üzerine bir araştırma. Yüksek Lisans Tezi, Selçuk Üni., Fen Bil. Ens., Konya, $77 \mathrm{~s}$.

Demir K, Elgün A, Argun MŞ (2009) Sütçülük yan ürünlerinden, peynir altı, yayık altı ve süzme yoğurt suları katkılarının bazı ekmek özelliklerine etkileri üzerine bir araştırma. Gıda, 34 (2): 99-106.

Dinçoğlu AH, Ardıç M (2012) Peynir altı suyunun beslenmemizdeki önemi ve kullanım olanakları Harran Üni. Vet. Fak. Derg. 1(1): 54-60.

D’Egidio MG, De Stefanis E, Fortini S, Galterio G, Nardi S, Sgrulletta D, Bozzini A (1982) Standardization of cooking quality analysis in macaroni and pasta products. Cereal Foods World, 27: 367-368.

Díaz-Ramírez M, Calderón-Domínguez G, García-Garibay $M$, Jiménez-Guzmán J, Villanueva-Carvajal A, SalgadoCruz MP, Arizmendi-Cotero D, Moral-Ramírez ED (2016) Effect of whey protein isolate addition on physical, structural and sensory properties of sponge cake. Food Hydrocolloids, 61: 633-639.

Ertugay Z, Elgün A, Koca $F$ (1987) Peyniraltı suyu ve tozunun hamur ve ekmek özelliklerine etkisi üzerinde bir araştırma. Gıda 12(3): 167-173. 
Gani A, Broadway A, Ahmad M, Ashwar BA, Wani AA, Wani SM, Masoodi FA, Khatkar BS (2015) Effect of whey and casein protein hydrolysates on rheological, textural and sensory properties of cookies. J. Food Sci. Tech. 52(9): 5718-5726.

Gökalp HY, Zorba Ö, Çağlar A, Özdemir S (1995) Süt bileşenleri ve süt mamullerinin et ve fırın ürünleri formülasyonlarında kullanılması. Gıda Derg. 20(1): 39-42.

Guimaraes PM, Teixeira JA, Domingues L (2010) Fermentation of lactose to bio-ethanol by yeasts as part of integrated solutions for the valorisation of cheese whey. Biotech. Adv. 28(3): 375-384.

Güler Z (2014) Profiles of organic acid and volatile compounds in acid-type cheeses containing herbs and spices (Surk cheese). Int. J. Food Properties, 17: 1379-1392.

Güzeler N, Esmek EE, Kalender M (2017) Peyniraltı suyu ve peyniraltı suyunun içecek sektöründe değerlendirilme olanakları. Çukurova J. Agric. Food Sci. 32(2): 27-36.

Hou GG (2010) Laboratory pilot-scale Asian noodle manufacturing and evaluation protocols, In: Asian Noodles: Science, Technology, and Processing. (Ed. Hou GG), John Wiley \& Sons, Inc., Hoboken, New Jersey.

IDF (1993) Milk determination of nitrogen content. Standard no. 20B. International Dairy Federation, Brussels, Belgium.

Karagözlü C, Bayarer M (2004) Peyniraltı suyu proteinlerinin fonksiyonel özellikleri ve sağlık üzerine etkileri. Ege Üni. Zir. Fak. Derg. 41(2): 197-207.

Kaur M, Singh V, Kaur R (2017) Effect of partial replacement of wheat flour with varying levels of flaxseed flour on physicochemical, antioxidant and sensory characteristics of cookies. Bioac. Carbohy. Dietary Fibre, 9: 14-20.

Kavaz-Yüksel A, Yüksel M, Ürüşan H (2019) Peynir altı suyunun çeşitli özellikleri ve kullanım olanakları. KSU J Eng Sci. 22(3): 114-125.

Konar A (1978) Yeni gelişmeler ışığında sütçülük artıklarının değerlendirilmesi ve ekonomik önemi. GIda Derg. 3(1): 35-46.

Koyuncu M, Tunçtürk $Y$ (2014) Sütçülük atık sularının arıtılma gereksinimi. Yüzüncü Yıl Üni. Fen Bil. Ens. Derg. 19 (1-2): 88-93.

Köksel H, Sivri D, Özboy Ö, Basman A, Karacan H (2000) Hububat Laboratuvarı El Kitabı. 91-100.

Kurt A, Gülümser S (1987) Peynir suyu kullanım imkanları. Atatürk Üni. Zir. Fak. Derg. 18(1-4): 133141.
Kurt A (1990) Süt Teknolojisi. Atatürk Üniversitesi Yayınları No: 573, Erzurum. $398 \mathrm{~s}$.

Marshall K (2004) Therapeutic applications of whey protein. Altern. Med. Rev. 9(2): 136-157.

Marques GA, Sao Jose JFB, Silva DA, Silva EMM (2016) Whey protein as a substitute for wheat in the development of no added sugar cookies. LWT - Food Sci. Tech. 67: 118-126.

Mete H (2012) Peynir altı suyunun ekmekçilikte değerlendirilmesi ve ekonomik önemi. Tekirdağ S.M.M.M. Odası Sos. Bil. Derg. 1: 1-10.

Oh NH, Seib PA, Deyoe CW, Ward AB, Deyoe CW (1985) Noodles. IV. Influence of flour protein, extraction rate, particle size and starch damage on the quality characteristics of dry noodles, Cereal Chem. 62(6): 441-446.

Özkaya H, Seçkin R, Ercan R (1984) Bazı makarna çeşitlerinin kimyasal bileşimi ve pişme kalitesi üzerine araştırma. Gıda Derg. 9(3): 133-161.

Patel RS, Jayaprakasha HM, Singh S (1991) Recent advances in concent ration and drying of whey. Indian-Dairyman, 4(39): 417-421.

Paul S, Kulkarni S, Rao KJ (2016) Effect of Indian cottage cheese (paneer)-whey on rheological and proofing characteristics of multigrain bread dough. J. Texture Stud. 47: 142-151.

Pérez S, Matta E, Osella C, Torre M, Sánchez HD (2013) Effect of soy flour and whey protein concentrate on cookie color. LWT - Food Sci. Tech. 50: 120-125.

Suleiman AA, Zhu KX, Peng W, Hassan HA, Obadi M, Siddeeg A, Zhou HM (2019) Rheological and quality characteristics of composite gluten-free dough and biscuits supplemented with fermented and unfermented Agaricus bisporus polysaccharide flour. Food Chem. 271: 193-203.

Tang X, Liu J (2017) A comparative study of partial replacement of wheat flour with whey and soy protein on rheological properties of dough and cookie quality. J. Food Quality, p 10.

TSE (2013) TS 591 Beyaz Peynir Standardı. Türk Standartları Enstitüsü, Ankara, Türkiye.

Yalcin S, Basman A (2008) Effects of gelatinisation level, gum and transglutaminase on the quality characteristics of rice noodle. Int. J. Food Sci. Tech. 43: 1637-1644.

Yamamoto H, Worthington ST, Hou G, Ng P (1996) Rheological properties and baking qualities of selected soft wheats in the United States. Cereal Chem. 73: 215-221. 
Yerlikaya O, Kınık Ö, Akbulut N (2010) Peyniraltı suyunun fonksiyonel özellikleri ve peyniraltı suyu kullanılarak üretilen yeni nesil süt ürünleri. Gıda Derg. 35(4): 289296.
Zhou J, Liu J, Tang X (2018) Effects of whey and soy protein addition on bread rheological property of wheat flour. J Texture Stud. 49: 38-46. 